\title{
PENDAMPINGAN LITERASI KEUANGAN PADA PENGUSAHA INDUSTRI KECIL GULA ONDRONG DEMI PERTAHANKAN EKSISTENSI USAHA
}

\author{
Ita Athia, Taufiqurrohman \\ Fakultas Ekonimi dan Bisnis, Universitas Islam Malang \\ *korespondensi email: itaathia@unisma.ac.id
}

\begin{abstract}
ABSTRAK
Keberadaan gula ondrong yang berlokasi di desa Sukolilo, kecamatan Wajak, kabupaten Malang, perlahan-lahan mulai menurun. Disinyalir yang menjadi permasalahn menurunnya usaha ini adalah kurangnya pengetahuan keuangan dari pemilik usaha dalam memperhitungkan biaya produksi, yang meliputi biaya bahan baku, upah tenaga kerja, biaya produksi, biaya pengemasan dan pemasarannya. Pendapatan yang diperoleh pelaku usaha seringkali tidak mampu menutup total biaya yang dikeluarkan, sehingga usaha sering mengalami kerugian. Pengabdian kepada masyarakat yang dilakukan oleh kelompok mahasiswa KSM (Kegiatan Sarjana Mengabdi) Unisma ini bertujuan untuk membantu pelaku usaha dalam menyusun penentuan Harga Pokok Produksi dan menentukan harga jual produk gula ondrong. Metode yang dilakukan adalah: (1). Wawancara dengan pemilik usaha, (2). Mengedukasi pemilik usaha tentang pentingnya memahami literasi keuangan usaha, (3). Pendampingan penyusunan Harga Pokok Produksi, (4). Pendampingan penentuan harga jual gula ondrong. Hasil dari kegiatan masyarakat ini adalah pengusaha industri gula ondrong mampu menentukan HPP dan harga jual gula ondrong yang telah disesuaikan.
\end{abstract}

Kata Kunci: gula ondrong; literasi keuangan; harga pokok produksi

\section{PENDAHULUAN}

Industri gula ondrong merupakan salah satu industri kecil yang mengangkat nama Desa Sukolilo, kecamatan Wajak, kabupaten Malang. Industri ini memiliki potensi yang besar dalam membangun perekonomian warganya. Ondrong berasal dari kata "ondrongan" yaitu kata yang dipakai untuk menyebut pabrik gula tradisional yang dikerjakan oleh masyarakat melalui usaha mikro dan kecil. Gula ondrong ini sendiri adalah gula yang dihasilkan dari percampuran antara tebu hijau dan tebu hitam yang mempunyai nilai rendemen di bawah angka delapan dan dimasak dengan menggunakan bahan bakar ampas tebu dan sampah plastik, sehingga menghasilkan gula berwarna coklat karamel. Gula ondrong yang dihasilkan ini nantinya didistribusikan pada beberapa CV dan pabrik sebagai bahan baku produksi kecap dan petis. Gula ondrong juga masih dikonsumsi oleh masyarakat sekitar, sehingga potensi pemasaran di pasar lokal juga lumayan bagus.

Potensi besar yang dihasilkan pemilik industri gula ondrong ini ternyata tidak diikuti dengan perolehan hasil atau profit yang cukup bagi pemilik usaha. Oleh karenanya perkembangan usaha gula ondrong ini tidak begitu menggembirakan. Berdasarkan hasil wawancara dan identifikasi permasalahan yang dihadapi pemilik usaha industri ondrong, diketahui bahwa keuangan perusahaan mulai tersendat. Ditambah dengan adanya pandemi covid 19 yang sangat berdampak pada menurunnya sebagian permintaan dan pesanan gula 
ondrong, sehingga mengikis cashflow yang dimiliki pemilik usaha. "Industri saya sering mengalami kerugian dan tidak bisa menutup ongkos produksi selama pandemi ini. Pendapatan yang kita peroleh tekor untuk menutup upah tenaga kerja, karena orderan tidak sebanyak dulu" kata pak Ibrahim, salah satu pemilik pabrik gula ondrong (gambar 1).

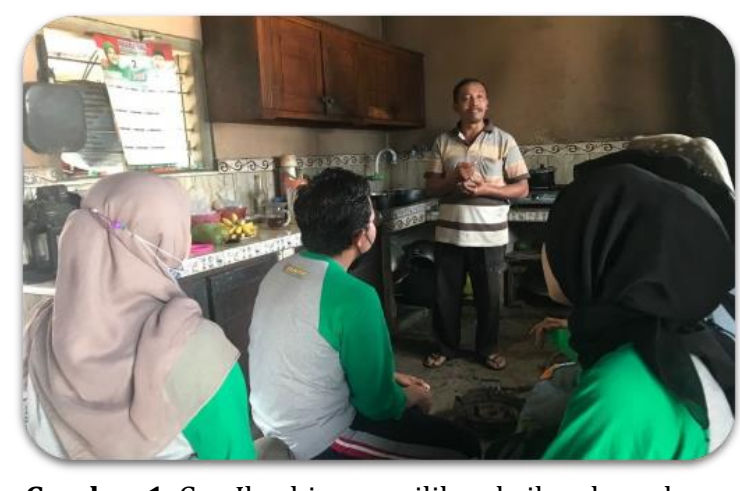

Gambar 1. Gus Ibrahim, pemilik pabrik gula ondrong

Dari informasi tersebut, maka bisa diidentifikasikan bahwa permasalahan krusial yang dihadapi pemilik adalah belum mampu menghitung dan merencanakan biaya produksi dengan adanya perubahan penurunan omzet penjualan. Pemberian literasi keuangan yang berhubungan dengan pengetahuan menentukan Harga Pokok Produksi dan penyesuaian pada penentuan harga jual produk dianggap sebagai solusi yang dapat membantu pemilik usaha gula ondrong untuk mengatasi permasalahannya.

Pengetahuan pengelolaan keuangan sangat diperlukan bagi pengusaha, terutama mengelola uang di masa perekonomian yang serba sulit seperti saat ini. Mengelola uang dimulai sejak perencanaan produksi, perencanaan tenaga kerja dan perencanaan pemasaran (Rizal et al., 2019; Sari, 2019). Indrayani (2020) menyampaikan bahwa setiap pengusaha harus "melek keuangan". Literasi keuangan dapat dijadikan pedoman yang sifatnya mendasar bagi pengusaha agar dapat meminimalisir kesalahan keuangan. Gavigan (2010) berpendapat bahwa pemilik usaha yang mengerti literasi keuangan dapat membuat keputusan keuangan yang tepat dan merencanakan kebutuhan finansial di masa depan.

Keutamaan pendampingan literasi keuangan pada pengusaha gula ondrong ini dirasa penting untuk menyelamatkan industri tersebut agar tidak terus merugi ketika pendapatannya menurun karena perubahan lingkungan. Tujuan pemberian edukasi literasi keuangan ini adalah membantu pengusaha dapat memperhitungkan beban biaya produksi dengan tepat, menyesuaikan upah tenaga kerja selama pandemi berlangsung serta menentukan harga jual yang telah disesuaikan dengan perubahan yang terjadi.

\section{METODE}

Lokasi pengabdian tim KSM Unisma dilakukan pada salah satu pemilik pabrik gula ondrong di desa Sukolilo, kecamatan Wajak, kabupaten Malang. Tim pengabdian terdiri dari lima orang mahasiswa Fakultas Ekonomi Bisnis Unisma jurusan Manajemen. Anggota tim pengabdi antara lain adalah Taufiqurrohman, Zakiyatul Fitriah, Evi Onalisa, Hikamtun Nafiah Ali dan Inestis S.C.A. Waktu pengabdian dilaksanakan pada minggu kedua hingga keempat bulan Agustus tahun 2021.

Metode pengabdian yang dilaksanakan dimulai dari: (1). Identifikasi masalah dengan cara melakukan silaturahmi dan wawancara dengan pemilik usaha, (2). Mengedukasi pemilik usaha tentang pentingnya memahami literasi keuangan usaha, (3). Pendampingan penyusunan Harga Pokok Produksi, (4). Pendampingan penentuan harga jual gula ondrong. 
Pada kegiatan pendampingan penyusunan Harga Pokok Produksi (HPP), tim pengabdi mengelompokkan keseluruhan biaya yang dikeluarkan pemilik pabrik selama produksi berlangsung setiap bulannya. Pendekatan perhitungan Harga Pokok Produksi (HPP) dalam kegiatan ini menggunakan metode full costing yaitu metode penentuan harga pokok produksi dengan memperhitungkan semua unsur biaya produksi (Hasibuan, 2016), yang meliputi: biaya bahan baku, biaya tenaga kerja langsung, biaya tetap, dan biaya variabel pabrik.

Kemudian untuk menentukan harga jual produk menggunakan metode cost plus pricing yaitu perhitungan total HPP ditambah dengan prosentase keuntungan yang diharapkan pemilik usaha. Harga jual yang baru juga masih disesuaikan dengan harga di pasaran agar tetap terjangkau oleh konsumen sekitar.

\section{HASIL DAN PEMBAHASAN}

Kabupaten Malang terkenal sebagai penghasil tanaman tebu yang melimpah. Hasil panenan tebu ini tidak semuanya terserap di dua pabrik gula yang berada di kabupaten Malang. Hasil panenan tebu yang mempunyai nilai rendemen rendah ini dimanfaatkan oleh masyarakat sekitar untuk diolah secara mandiri menjaddi gula merah, yang oleh masyarakat sekitar lebih dikenal sebagai gula ondrong. Hasil panen tebu diperas untuk diambil airnya, kemudian dimasak menggunakan wajan besar sambil diaduk-aduk hingga mengental. Setelah itu dimasukkan ke dalam wadah yang menyerupai bak besar yang dipakai sebagai tempat penganginan. Gula yang dianginkan terus dibolak-balik hingga dingin, kering dan menggumpal. Proses produksi gula ondrong dapat dilihat di gambar 2 .

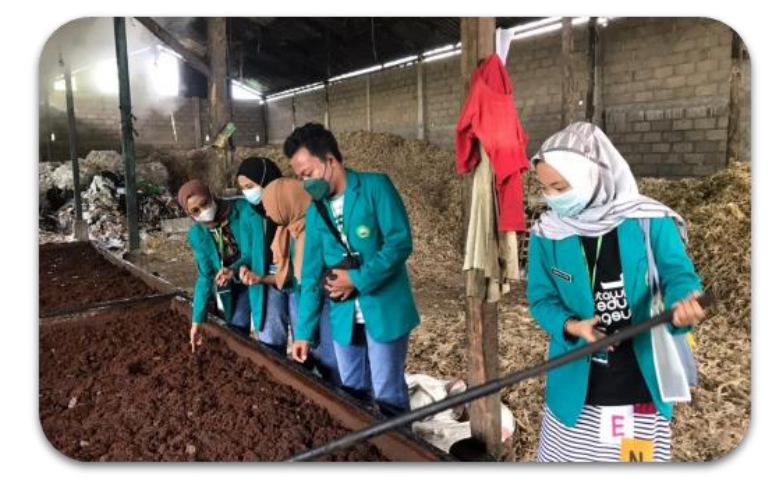

Gambar 2. Proses produksi dan pendinginan gula ondrong

Gula merah ondrong yang sudah kering, siap dipasarkan tanpa perlu dicetak, dan langsung dijual per kilo atau dalam partai besar apabila untuk keperluan pasokan ke pabrikan kecap dan petis. Gula ondrong banyak dikirim ke pabrik-pabrik kecap dan petis di sekitar Malang, Jombang, Pasuruan, Tulungagung, Kediri, Surabaya hingga Madura. Sedangkan untuk pasar lokal, gula ondrong banyak dimanfaatkan oleh warung dan ibu-ibu sekitar. Untuk menghemat biaya produksi, pengusaha gula ondrong memanfaatkan ampas tebu dan limbah plastik sebagai bahan bakar untuk memasak gula ondrong (gambar 3 ). 


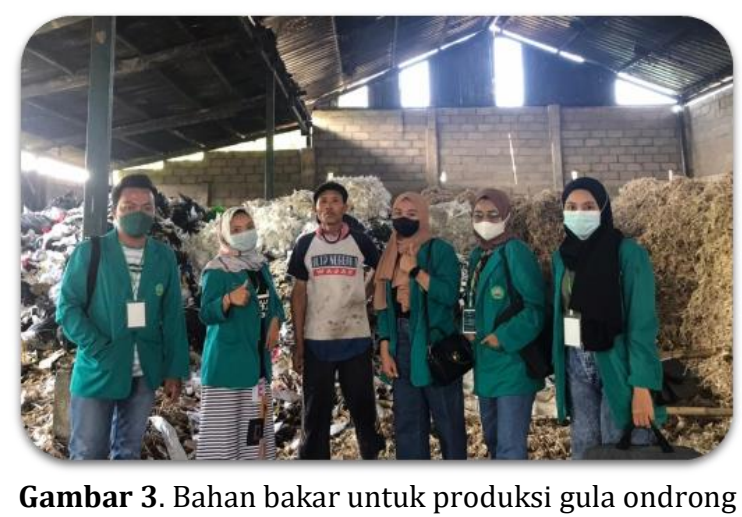

Harga pokok produksi menurut Supriyono (2012) adalah semua pengeluaran yang dilakukan perusahaan untuk memperoleh faktor-faktor produksi dan bahan mentah yang akan digunakan untuk menciptakan barang-barang yang diproduksi perusahaan tersebut. Selama ini pak Ibrahim tidak pernah mencatat pengeluaran produksi secara pasti. Pengeluaran dan pendapatan dicatat seadanya dan ditulis manual. Sehingga pak Ibrahim sulit untuk menentukan jumlah biaya yang dikeluarkan setiap bulannya secara pasti. Untuk menentukan besarnya HPP, maka semua biaya yang dikeluarkan oleh perusahaan harus dikumpulkan dan dicatat dengan benar. Adapun biaya yang dikeluarkan oleh pak Ibrahim selaku pengelola pabrik gula ondrong dalam satu bulannya tersaji dalam tabel 1 .

Tabel 1. Rekapitulasi biaya produksi gula ondrong

\begin{tabular}{cllrrrr}
\hline No & Komponen Biaya & Jenis Biaya & Harga & Satuan & Kuantitas & Jumlah \\
\hline 1. & Biaya bahan baku & Tebu & 30.000 & kuintal & 8 ton/hari & 2.400 .000 \\
2. & Biaya tenaga kerja & Upah & 1.100 .000 & hari & 1 & 1.100 .000 \\
3. & Biaya tetap & Alat produksi & 300.000 & hari & 1 & 300.000 \\
4. & Biaya variabel & Listrik, air, BBM & 240.000 & hari & 1 & 240.000 \\
\multicolumn{2}{c}{ Total } & & & & 4.040 .000 \\
\hline
\end{tabular}

Menurut informasi dari pak Ibrahim, kapasitas pabrik dalam mengolah gula tebu sekitar 7/8 ton sehari. Pasokan tebu didatangkan dari ladang sendiri di daerah Dampit, Poncokusumo, kabupaten Malang dengan harga kulak Rp. 28.000,- sampai Rp. 30.000,/kuintal. Dari kapasitas produksi 7/8 ton tersebut, dihasilkan 10/11 kuintal gula ondrong untuk setiap hari produksi. Harga gula di pasar lokal dihargai sekitar Rp. 5.000,- sampai Rp. 7.000,-/kg nya. Sedangkan untuk harga gula ondrong bongkahan dihargai sekitar Rp. 4.000,sampai Rp. 4.500,- /kg nya. Sehingga apabila diperhitungkan HPP produksi gula ondrong per kilogramnya dapat ditunjukkan pada tabel 2.

Tabel 2. Perhitungan HPP gula ondrong $/ \mathrm{kg}$

\begin{tabular}{ccrcccc}
\hline $\begin{array}{c}\text { Bahan } \\
\text { Baku }\end{array}$ & Upah & $\begin{array}{c}\text { Alat } \\
\text { produksi }\end{array}$ & $\begin{array}{c}\text { Listrik, } \\
\text { Air, BBM }\end{array}$ & Total & $\begin{array}{c}\text { Jumlah } \\
\text { Produksi }\end{array}$ & $\begin{array}{c}\text { HPP } \\
\text { Satuan/kg } \\
\text { (Rp) }\end{array}$ \\
\hline 2.400 .000 & 1.100 .000 & 300.000 & 240.000 & 4.040 .000 & 10 kuintal & 4.040 \\
\hline
\end{tabular}

Dari ilustrasi perhitungan dan informasi pemilik usaha di atas, bisa dilihat keuntungan yang didapatkan oleh pemilik sangat tipis. Dalam kondisi normal yang tingkat permintaan dan orderan lancar, bisa jadi keuntungan yang dirasakan pemilik dirasa lumayan bahkan besar. Tetapi dalam kondisi pandemi seperti ini, tingkat pemesanan dan permintaan mengalami penurunan, sehingga berimbas pada kelancaran cashflow yang diterima oleh pengusaha. Seringkali pak Ibrahim merasakan pendapatan yang dia terima tidak dapat menutup biaya yang dikeluarkan untuk para pekerjanya. 
Dengan memahami pentingnya literasi keuangan bagi usaha, pak Ibrahim dapat mengetahui biaya operasional dan produksi yang telah dikeluarkan secara tepat dan tidak berdasar kira-kira. Dari identifikasi seluruh biaya produksi tersebut, pak ibrahim dapat memperhitungkan berapa harga jual yang seharusnya ditawarkan pada pabrikan dan pasar lokal.

Setelah diketahui dengan pasti jumlah Harga Pokok Produksinya, maka langkah selanjutnya adalah menentukan harga jual yang seharusnya ditawarkan pada pasar. Pendekatan penentuan harga jual menggunakan metode cost plus pricing. Cost Full Pricing adalah harga jual atas barang dan jasa dalam keadaan normal dengan menambah laba yang diharapkan di atas biaya penuh masa yang akan datang untuk memperoleh barang dan jasa (Mulyadi, 2012). Menurut Kristanti dalam Noviasari \& Alamsyah (2020) metode cost plus pricing semakin perusahaan memproduksi dalam jumlah yang banyak maka harga jualnya semakin murah, sebaliknya semakin perusahaan memproduksi daam jumlah sedikit maka harga jual semakin mahal. Rumus sederhana yang dipakai menghitung harga jual dengan metode ini adalah: Harga Jual = taksiran full costing + margin laba.

Dengan demikian pak Ibrahim bisa menentukan harga "pasti" yang ditawarkan pada pasar. Semisal pak Ibrahim menghendaki prosentase laba atau keuntungan yang dia peroleh sebesar 20\%. Dengan demikian harga jual yang bisa ditawarkan pak Ibrahim dengan menggunakan metode cost plus pricing adalah: $4.040+(20 \% \times$ Rp. 4.040$)=4.848$. Berdasarkan perhitungan tersebut, maka harga jual yang direkomendasikan (terutama harga jual gula ondrong untuk pabrikan) sekitar Rp. 5.000,-/kg.

\section{KESIMPULAN}

Berdasarkan hasil kegiatan pengabdian yang telah dijalankan, dapat ditarik kesimpulan bahwa, kebutuhan literasi keuangan yang selama ini kurang diketahui pengusaha, ternyata perannya sangat penting. Literasi keuangan dibutuhkan untuk mengelola perusahaan dengan perhitungan yang tepat dan keuangan yang dijalankan dengan baik akan membantu pengusaha mempertahankan eksistensi usahanya. Dengan mengetahui perhitungan Harga Pokok Produksi secara pasti, memudahkan pengusaha dalam menentukan harga jual produk di pasaran dan dapat melihat besarnya keuntungan dengan pasti. Harapannya adalah dengan literasi keuangan ini, eksistensi usaha gula ondrong khususnya, dan usaha mikro, kecil dan menengah lainnya bisa terus berkelanjutan.

\section{UCAPAN TERIMA KASIH}

Terima kasih sebesar-besarnya kepada civitas akademika Universitas Islam Malang terutama kepada pihak lembaga pengabdian dan pemberdayaan masyarakat Universitas Islam Malang yang telah diberi kesempatan untuk menimba ilmu yang sangat penting dan bermanfaat. Kemudian terima kasih kepada pemilik gula ondrong Desa Sukolilo Kecamatan Wajak Kabupaten Malang dan seluruh karyawan yang telah mengijinkan tim pengabdi melakukan pengabdian.

\section{DAFTAR RUJUKAN}

Gavigan, K. (2010). Show Me the Money Resources: Financial Literacy for 21st-Century Learners. Library Media Connection, 28(5), 24-27.

Hasibuan, M. S. (2016). Analisis Perhitungan HPP Menentukan Harga Penjualan yang Terbaik $\begin{array}{llll}\text { untuk UKM. } & \text { Teknovasi, } & \text { 3(2), } & \text { 10-16. }\end{array}$ https://ejurnal.plm.ac.id/index.php/Teknovasi/article/view/65

Indrayani, L. (2020). Makna Literasi Keuangan dalam Keberlangsungan Usaha Industri Rumah Tangga Perempuan Bali. JIA (Jurnal Ilmiah Akuntansi), 5(2), 407-428. 
https://doi.org/10.23887/jia.v5i2.29858

Mulyadi. (2012). Akuntansi Biaya (5th ed.). Unit Penerbit dan Percetakan Sekolah Tinggi Ilmu Manajemen YKPN.

Noviasari, E., \& Alamsyah, R. (2020). Peranan Perhitungan Harga Pokok Produksi Pendekatan Full Costing Dalam Menentukan Harga Jual Dengan Metode Cost Plus Pricing: Studi Kasus pada UMKM Sepatu Heriyanto. Jurnal Ilmiah Akuntansi Kesatuan, 8(1), 17-26. https://doi.org/10.37641/jiakes.v8i1.287

Rizal, M., Mustapita, A. F., \& Kartika Sari, A. F. (2019). Pelatihan Untuk Pengajuan Pembiayaan Mudharabah Perbankan Syariah Sebagai Peningkatan Kinerja UMKM. Jurnal Inovasi Hasil Pengabdian Masyarakat (JIPEMAS), 3(1), 15-22. https://doi.org/10.33474/jipemas.v3i1.2569

Sari, D. E. (2019). Sosialisasi dan Edukasi Literasi Keuangan Untuk Warga 'Aisyiyah Kabupaten Sukoharjo Guna Mengurangi Perilaku Konsumtif Pada Remaja dan AnakAnak. Jurnal Inovasi Hasil Pengabdian Masyarakat (JIPEMAS), 2(2), 88-99. https://doi.org/10.33474/jipemas.v2i2.2694

Supriyono. (2012). Akuntansi biaya : pengumpulan biaya dan penentuan harga pokok. BPFE. 